\title{
Pengetahuan dan Keterampilan Bantuan Hidup Dasar Serta Penanganan Tersedak Pada Siswa SMA
}

\author{
Edi Purnomo ${ }^{1}$, Akbar Nur ${ }^{2 *}$, Zulhaini Sartika A. Pulungan ${ }^{3}$, Andi Nasir ${ }^{4 *}$ \\ 1,3,4 Program Studi Ilmu Keperawatan Poltekkes kemenkes Mamuju, 91511, Sulawesi Barat, Indonesia \\ ${ }^{2}$ Program Studi Ilmu Keperawatan STIKES Andini Persada, 91511, Sulawesi Barat, Indonesia \\ *Korespondensi : akbarskep@gmail.com
}

\begin{abstract}
Abstrak: Gawat darurat merupakan suatu kejadian yang terjadi secara mendadak sehingga mengakibatkan seseorang memerlukan penanganan dan pertolongan secara cepat dan tepat. Salah satu tindakan yang dapat dilakukan masyarakat awam dan tenaga medis dalam menangani kasus gawat darurat yaitu dengan memberikan Bantuan Hidup Dasar (BHD) dan Basic Life Support (BLS) yang merupakan suatu usaha mencegah terjadinya henti jantung dan henti napas. Tujuan: penelitian ini dilakukan guna untuk mengetahui pengaruh edukasi Bantuan Hidup Dasar (BHD) dan penanganan tersedak terhadap peningkatan pengetahuan dan keterampilan siswa SMAN 3 Mamuju. Penelitian ini menggunakan One-Group pre test-post test design guna untuk mengetahui pengetahuan dan keterampilan dalam penanganan Bantuan Hidup Dasar (BHD) dan penanganan tersedak pada siswa SMAN 3 Mamuju. Subjek yang digunakan dalam penelitian ini adalah siswa SMAN 3 Mamuju dengan total responden sebanyak 35 siswa. Analisis data penelitian menggunakan SPSS dan uji hipotesis menggunakan Paired t-test. Hasil uji statistic dengan Paired t-test terdapat pengaruh signifikan sebelum dan setelah diberikan pelatihan Bantuan Hidup Dasar (BHD) dan penanganan tersedak dengan nilai signifikansi $p$ value $=0,001$ pengetahuan, keterampilan BHD $P$ Value $=0,002$ dan keterampilan penanganan tersedak $P$ Value $=0,001$ dengan taraf signifikansi $0,05(\mathrm{P}<0,05)$. Kesimpulan Pelatihan Bantuan Hidup Dasar (BHD) dan penanganan tersedak efektif untuk meningkatkan pengetahuan, keterampilan Bantuan Hidup Dasar dan keterampilan penanganan tersedak siswa SMAN 3 Mamuju sehingga diharapkan penanganan kasus gawat darurat yang dapat ditemui dilapangan dapat diatasi dengan cepat dan tepat.
\end{abstract}

Kata kunci: Pelatihan, Pengetahuan, Keterampilan BHD, Tersedak

Abstract: An Emergency is an event that occurs suddenly to cause a person to need treatment and help quickly and accurately. One of the actions that can be done by ordinary people and medical personnel in handling emergency cases is to provide Basic Life Support (BLS) which is an effort to prevent the occurrence of cardiac arrest and respiratory arrest. Objective: This research was conducted to determine the effect of Basic Life Support (BLS) and handling of choking on improving the knowledge and skills of students of Senior High School3 Mamuju Method: This study used a One-group pre-test-post test design to find out knowledge and skills in handling Basic Life Assistance (BLS) and choking treatment in Mamuju 3 High School students. The subjects used in this study were students of Senior High School 3 Mamuju with a total of 35 respondents. Analysis of research data using SPSS and hypothesis testing using the Paired $t$-test. Statistical test results with Paired t-test had a significant influence before and after Basic Life Assistance (BLS) training and choking treatment with a significance value $p$-value $=0.001$ knowledge, Basic Life Support skills P-Value $=0.002$ and choking handling skills $P$-Value $=0.001$ with a significance level of $0.05(P<0.05)$. As conclusion, Basic Life Assistance Training (BHD) and effective choking management to improve the knowledge, BHD skills and choking handling skills of SMuju 3 Mamuju students so that it is expected that handling emergency cases that can be found in the field can be dealt with quickly and appropriately. 
Keywords: BHD Training, Knowledge, Skills, Choking

\section{PENDAHULUAN}

Keterampilan Bantuan Hidup Dasar (BHD) atau Basic Life Support (BLS) dapat diajarkan kepada masyarakat umum dan tidak hanya dilakukan oleh tenaga kesehatan namun termasuk masyarakat umum. Saat ini diharapkan kepada setiap orang harus memiliki kemampuan dalam memberikan pertolongan bantuan hidup dasar (BHD) dan basic life support (BLS) kemampuan ini diharapkan karena didalamnya telah diajarkan keterampilan dan teknik dasar dalam melakukan pertolongan kepada korban dari berbagai kecelakaan maupun kejadian yang tidak diharapkan (Frame, 2010; Fajarwati, 2012)

Penyebab kematian utama di dunia disebabkan oleh penyakit jantung. Berdasarkan (World Health Organization, 2015), menyatakan bahwa terdapat 17,5 juta kasus di Dunia yang meninggal akibat penyakit jantung dan pembuluh darah. Setiap tahun angka kasus terus meningkat, terdapat $31 \%$ dari 56,5 juta kematian di seluruh Dunia. Lebih dari 3/4 kematian karena penyakit kardiovaskuler yang terjadi di Negara berkembang yang memiliki penghasilan rendah hingga sedang (Kemenkes RI, 2017). Tiap tahunnya di Amerika terjadi 420.000 kasus henti jantung (AHA, 2011, Meaney et al., 2013). Henti jantung adalah kasus gawat darurat karena dapat terjadi secara tiba-tiba dan membutuhkan penanganan yang cepat dan tepat. Jika tidak diberikan bantuan hidup dasar dengan cepat, korban dapat meninggal.Terdapat sebanyak 12.400 kasus tersedak pada anak dibawah umur 14 tahun dari tahun 2001 hingga tahun 2009 yang datang ke Instalasi Gawat Darurat ( Kemenkes RI, 2018). Berdasarkan data dari Centers of Disease Control and Prevention menyatakan bahwa terdapat 34 anak yang dibawa ke IGD setiap hari karena tersedak dengan benda asing dan sebanyak 57 anak yang meninggal setiap tahunnya karena tidak mendapatkan pertolongan yang tepat pada saat tersedak (Sumarningsih, Prihatiningsih, 2015).

Sumbatan jalan napas atau dikenal dengan istilah tersedak termasuk kondisi gawat darurat yang harus segera ditangani.Tersedak merupakan salah satu kegawatan pada pernapasan yang dapat mengancam nyawa karena bila dibiarkan terlalu lama, tubuh dapat mengalami kekurangan oksigen (hipoksia) dan dapat mengakibatkan kematian (Mommychi, 2014). Tersedak (choking) merupakan penyebab penyumbatan jalan napas dimana dapat berakibat fatal apabila mengarah pada gangguan ventilasi dan oksigenasi pada tubuh sehingga tersedak dapat menyebabkan kematian (American Heart Association, 2015). Tersedak merupakan kejadian gawat darurat penyebab salah satu kematian anak tertinggi, khususnya anak usia 3 tahun. Tersedak sering disebabkan oleh makanan, koin, maupun mainan. Pengalaman kegawatdaruratan membuat masyarakat awam tergerak untuk mengetahui hal-hal apa saja yang dapat dilakukan selama menunggu pertolongan medis. Dengan mengetahui beberapa kasus kegawatdaruratan yang telah terjadi, diharapkan masyarakat dapat memberikan atau melakukan pertolongan yang cepat dan tepat pada kasus tersebut.

Berdasarkan hasil penelitian yang dilakukan oleh (Lestari, 2014), bahwa pelatihan BHD terhadap tingkat motivasi dalam menolong korban yang mengalami henti jantung telah menunjukkan hasil adanya peningkatan motivasi setelah diberikan pelatihan sedangkan penelitian yang dilakukan oleh (Christie Lontoh, Maykel Kiling, 2013) menjelaskan bahwa terdapat peningkatan pengetahuan RJP dari 8,3\% menjadi 94,4\%. Penelitian yang dilakukan di Amerika Serikat menyatakan bahwa pasien yang telah henti jantung dan mendapatkan BLS memiliki tingkat survival yang tinggi (Sanghavi et al., 2015). Pelatihan bantuan hidup dasar (BHD) dan penanganan tersedak terhadap peningkatan pengetahuan dan keterampilan siswa SMAN 3 Mamuju. Diharapkan dapat lebih meningkatkan kewaspadaan terhadap kegawatdaruratan sehari-hari yang mungkin terjadi dan dapat mengantisipasinya dengan baik sehingga korban dapat penanganan yang cepat, tepat, dan efektif. 


\section{METODE}

Dalam penelitian ini menggunakan desain One Group Pre Test-Post Test Design karena pada penelitian ini tidak menggunakan kelompok kontrol. Penelitian ini dilaksanakan pada bulan Juli Tahun 2019. Populasi dalam penelitian ini adalah siswa SMAN 3 Mamuju adapun sampel pada penelitian ini sebanyak 35 responden yang terdiri dari siswa kelas XI dan XII IPA dan IPS yang terdiri dari anggota PMR, PMI, Pramuka, Paskibra dan OSIS. Teknik pengumpulan data dalam penelitian ini menggunakan lembar informed consent, dengan menjelaskan tujuan dan manfaat penelitian kepada responden. Setelah semua responden setuju dan menandatangani informed consent dilakukan pre test dengan menggunakan kuesioner bantuan hidup dasar (BHD) dan penanganan tersedak guna untuk mengetahui tingkat pengetahuan siswa sebelum diberikan pelatihan BHD dan penanganan tersedak. Setelah pelatihan BHD dan penanganan tersedak responden kembali dilakukan post-test guna untuk mengetahui tingkat pengetahuan, keterampilan BHD dan keterampilan penanganan tersedak. Setelah diberikan pelatihan, selanjutnya para siswa dilatih untuk menerapkan hasil pelatihan dalam mencegah kematian atau kecacatan pada korban kegawatdaruratan dan penanganan tersedak yang terjadi di lingkungannya.

Instrumen dalam penelitian ini menggunakan kuesioner, instruktur, alat peraga (Phantom), dan Standar Prosedur Operasional (SPO) Penanganan Bantuan Hidup Dasar (BHD) dan penanganan tersedak (gawat darurat). Adapun bahan yang digunakan dalam penelitian ini adalah; Materi BHD (modul) dan peralatan media visual untuk penunjang dalam melakukan simulasi/praktikum. Analisis data, Setelah post test dilakukan maka peneliti melakukan pengolahan data dengan tahap coding, tabulating, editing, cleaning, dan describing. Setelah selesai di tabulasi data dianalisis menggunakan IBM SPSS versi 16 dengan uji statistic deskriptif, dan Paired $t$-test.

\section{HASIL}

Tabel 1 Tingkat Pengetahuan Siswa Sebelum dan Sesudah diberikan Pelatihan BHD dan Penanganan Tersedak

\begin{tabular}{ccccc}
\hline & Pre-test & & \multicolumn{2}{c}{ Post-test } \\
\hline Pengetahuan & F & \% & F & \% \\
\hline Baik & 18 & 51.4 & 29 & 82.9 \\
Kurang & 17 & 48.6 & 6 & 17.1 \\
\hline Total & 35 & 100 & 35 & 100 \\
\hline
\end{tabular}

Paired t-test $\alpha=0,000$

Berdasarkan tabel 1, tingkat pengetahuan siswa sebelum diberikan pelatihan bantuan hidup dasar (BHD) dan penanganan tersedak, yang memiliki pengetahuan baik 18 (51,4\%) responden, kurang 17 $(48,6 \%)$ responden dan setelah diberikan pelatihan BHD dan penanganan tersedak dimana responden yang memiliki pengetahuan kurang berjumlah 6 (17.1) responden dan kategori baik sebanyak 18 (82.9\%) responden. Hasil uji pairet $t$-test dengan nilai signifikansi $0.000(\mathrm{p}<0,05)$.

Selanjutnya, tabel 2 dan 3 menyajikan tingkat keterampilan siswa tentang BHD dan penanganan tersedak. Tingkat keterampilan siswa dalam melakukan BHD sebelum pelatihan terdapat 24 (68,6\%) responden memiliki keterampilan baik, 5 (14,3\%) responden cukup dan $6(17,1$ $\%)$ responden yang memiliki keterampilan kurang. Namun setelah diberikan pelatihan keterampilan terdapat $28(80 \%)$ responden yang baik, $7(20 \%)$ baik dan kurang $0(0 \%)$ responden. Hasil uji paired $t$-test dengan nilai signifikansi $0.002(\mathrm{p}<0,05)$. 
Tabel 2 Tingkat Keterampilan Siswa Sebelum Dan Sesudah Pelatihan BHD

\begin{tabular}{ccccc}
\hline & Pre-test & \multicolumn{3}{c}{ Post-test } \\
\hline $\begin{array}{c}\text { Keterampilan } \\
\text { BHD }\end{array}$ & F & \% & F & \% \\
\hline Baik & 24 & 68.6 & 28 & 80 \\
Cukup & 5 & 14.3 & 7 & 20 \\
Kurang & 6 & 17.1 & - & - \\
\hline Total & 35 & 100 & 35 & 100 \\
\hline
\end{tabular}

Paired $t$-test $\alpha=0,002$

Tabel 3 Tingkat Keterampilan Siswa Sebelum Dan Sesudah Pelatihan Penanganan Tersedak

\begin{tabular}{ccccc}
\hline & Pre-test & & \multicolumn{2}{c}{ Post-test } \\
\hline $\begin{array}{c}\text { Keterampilan } \\
\text { penanganan } \\
\text { tersedak }\end{array}$ & F & \% & F & $\%$ \\
\hline Baik & 6 & 22.9 & 18 & 48.6 \\
Cukup & 21 & 60 & 17 & 51.4 \\
Kurang & 8 & 17.1 & - & - \\
\hline Total & 35 & 100 & 35 & 100 \\
\hline
\end{tabular}

\section{Paired t-test $\alpha=0,000$}

Sebelum dilakukan pelatihan penanganan tersedak, keterampilan baik sebanyak $6(22,9 \%)$ responden, cukup $21(60 \%)$ responden dan kurang sebanyak $8(17,1 \%)$ responden. Setelah dilakukan pelatihan, terdapat $18(48,6)$ responden yang memiliki keterampilan baik, cukup $17(51,4 \%)$ responden dan kurang sebanyak $0(\%)$ responden. Hasil uji pairet $t$-test dengan nilai signifikansi 0.000 $(\mathrm{p}<0,05)$.

\section{PEMBAHASAN}

Hasil pada penelitian ini menunjukkan bahwa terdapat pengaruh pelatihan dengan menggunakan metode diskusi serta simulasi tentang bantuan hidup dasar dan penanganan tersedak dengan tingkat pengetahuan dan ketrampilan anak SMA 3 Mamuju. Hal ini terlihat dari peningkatan skor pengetahuan, keterampilan bantuan hidup dasar (BHD) dan keterampilan penanganan tersedak, peserta sebelum dan sesudah diberikan pelatihan. Hal ini sesuai dengan teori WHO yang dikutip dalam Notoatmodjo bahwa salah satu cara untuk meningkatkan pengetahuan adalah dengan cara memberikan informasi yang dapat diberikan dengan menggunakan metode edukasi.

Salah satu dasar yang harus dimiliki masyarakat umum adalah pengetahuan dalam menangani pasien tersedak dan henti napas maupun henti jantung karena BHD dan BLS idealnya tidak hanya diketahui oleh tenaga medis saja, hal ini dikarenakan banyaknya kasus gawat yang ditemukan oleh masyarakat awam sehingga dianggap perlu dan penting orang awam untuk mengetahui dan memahami Teknik BHD dan penanganan tersedak. Diharapkan suatu saat ketika orang awam telah menemukan kondisi gawat darurat seperti henti napas, henti jantung dan tersedak benda asing yang dapat menyebabkan henti nafas orang awam tersebut dapat memberikan pertolongan segera dan dapat mengupayakan korban dapat bertahan hidup. Penanganan pada kasus henti napas, henti jantung dan tersedak berdasarkan pengetahuan dan keterampilan yang dimiliki 
juga dapat menyelamatkan nyawa seseorang pada masalah medis akut, sehingga pelatihan dan penanganan tersedak dapat diatasi dan ditangani dengan cepat dan tepat (Nur, 2017).

Menurut (Notoatmodjo, 2012), mengemukakan bahwa pemberian edukasi berbasis media, $\mathrm{VCD}$, dan televisi lebih tinggi intensitasnya dibanding dengan menggunakan metode ceramah. Walaupun dengan intensitas yang rendah, media sederhana yang dapat dilakukan dengan menggunakan lembar balik, leaflet, poster, buku yang memuat gambar dapat memberikan beberapa keuntungan, yaitu dengan menggunakan bahasa atau istilah yang lebih mudah dipahami oleh masyarakat umum, mencerminkan kebiasaan, kehidupan, dan kepercayaan pada masyarakat setempat, dan sasaran dapat menyesuaikan dan belajar mandiri secara praktis karena dapat mengurangi kebutuhan mencatat, selain itu dapat memberikan informasi yang lebih detail, mudah dibuat, diperbanyak, diperbaiki, serta mudah disesuaikan dengan kelompok yang akan diberikan. Sehingga pada penelitian ini menggunakan metode diskusi, penyuluhan, serta simulasi.

Sampai saat ini belum ada data yang jelas terkait pengetahuan, dan kesiapan masyarakat dalam melakukan BHD untuk menghadapi situasi kegawatdaruratan. Dalam kondisi kegawatdaruratan menuntut seseorang baik secara individu, kelompok maupun masyarakat agar dapat mengetahui dan mandiri dalam memberikan pertolongan pertama, karena kebutuhan sebagian besar orang pada akhirnya akan berada dalam situasi yang memerlukan pertolongan pertama untuk orang lain atau diri mereka sendiri (Thygerson, 2009). Sehingga menjadikan pendidikan masyarakat melibatkan masyarakat sebagai penolong pertamanya (Vandeput, Tanner and Boswick, 1997), Salah satu lapisan masyarakat yang berkompetensi untuk dilatih adalah para siswa Sekolah Menengah Atas (SMA) dimana mereka berada pada kelompok usia remaja yang rentan terjadi situasi kegawatdaruratan tersebut.

Kematian dan penanganan tersedak yang kurang tepat/salah merupakan akibat dari kurangnya pengetahuan yang dapat berpengaruh pada perilaku seseorang dalam penanganan tersedak. Karena pengetahuan merupakan hasil tahu, sehingga hal ini dapat terjadi setelah seseorang melakukan pengamatan dan penginderaan pada yang telah dilihat, dimana pengetahuan dapat mendasari terbentuknya perilaku seseorang (Herawati and Purwanti, 2018). Hal ini sejalan dengan penelitian yang dilakukan oleh (Akbar Nur, Nur Amalia, Muhammad Jufri Badau, 2020; Kalsum and Nur, 2020), yang menunjukkan bahwa pasien yang memiliki tingkat pengetahuan yang baik, maka akan memberikan perilaku yang baik dan benar terhadap pencegahan penyakit. Bila seseorang atau masyarakat penanganan tersedak benar, maka akan terhindar dari ancaman benda asing yang dapat menyebabkan kematian. Hasil penelitian yang dilakukan oleh (Dwi Sumarningsih, 2015), diperoleh 20 data keluarga yang memiliki anak usia BALITA diperoleh data $25 \%$ mengemukakan bahwa cara mengatasi kasus tersedak dengan menepuk bagian pundak anak, sedangkan 75\% keluarga mengatakan bahwa penanganan tersedak dengan cara memberikan minum yang banyak namun apabila benda penyebab tersedak belum berhasil dikeluarkan barulah dibawah ke pelayanan kesehatan.

Hasil Penelitian ini sejalan dengan beberapa teori diatas, dimana terlihat pada peserta saat dilakukan pre-test sebagian besar peserta memiliki pengetahuan, keterampilan BHD dan penanganan tersedak dalam kategori kurang dan cukup. Namun setelah dilakukan post test sebagian besar responden memiliki pengetahuan, keterampilan BHD dan penanganan tersedak dalam kategori baik hal ini dipengaruhi beberapa faktor diantaranya tingkat konsentrasi dan kenyamanan peserta saat menerima materi dan pelatihan, pemateri yang telah menyampaikan materi dan simulasi yang jelas serta didukung dengan lingkungan yang nyaman. 


\section{KESIMPULAN}

Hasil penelitian ini menunjukkan bahwa pelajar sebagai orang awam dapat memberikan pertolongan pertama kepada siapapun dalam keadaan gawat darurat terutama pada seseorang yang mengalami henti napas, henti jantung, dan tersedak, setelah dilakukan penelitian ini terdapat peningkatan pengetahuan, dan keterampilan Bantuan Hidup Dasar (BHD) serta keterampilan dalam memberikan penanganan tersedak pada siswa SMAN 3 Mamuju dalam melakukan penanganan/pertolongan gawat darurat khususnya penanganan BHD dan tersedak.

\section{DAFTAR PUSTAKA}

Akbar Nur, Nur Amalia, Muhammad Jufri Badau, A. T. S. (2020) ‘Penyuluhan Penyakit Kusta dengan Tingkat Pengetahuan Keluarga Penderita Kusta di Wilayah Kerja Puskesmas Banggae II Kabupaten Majene', Jurnal Penelitian Kesehatan Suara Forikes, 11(4), pp. 73-76.

American Heart Association (2015) Fokus Utama Pembaruan Pedoman American Heart Association 2015 untuk CPR. Available at: https://www.coursehero.com/file/32283772/2015-AHA-Guidelines-Highlights-Indonesianpdf/ (Accessed: 27 August 2019).

Christie Lontoh, Maykel Kiling, D. W. (2013) 'Pengaruh Pelatihan Teori bantuan Hidup Dasar terhadap Pengetahuan Resusitasi Jantung Paru', Jurnal Keperawatan, 1.

Dwi Sumarningsih (2015) Pengaruh Edukasi Keluarga Tentang Pencegahan Tersedak Pada Anak Terhadap Pengetahuan Dan Keterampilan Keluarga Dusun Ngebel RT 09 Tamantirto Kasihan Bantu. Yogyakarta.

Erna Dwi Wahyuni, Deni Yasmara, S. E. all (2018) `Pemberdayaan Masyarakat ( Guru Dan Orang Tua ) Tanggap Bahaya Tersedak Di KB-TK Khadijah Surabaya Community Empowerment ( Teachers and Parents ) to Respond Choking Hazard in KB- TK Khadijah Surabaya', pp. 25-31.

Fajarwati, D. (2012) 'Basic Life Support tim bantuan medis FK UII', Di unduh dari http:// medicine. uii. ac. id/index. php/berita/Basic-Life-Support-Tim-Bantuan-Medis-FK-UII. html.

Frame, S. B. (2010) 'PHTLS: basic and advanced prehospital trauma life support', Missouri: Mosby.

Herawati, E. and Purwanti, O. S. (2018) 'Hubungan Antara Pengetahuan Dengan Efikasi Diri Penderita Tuberkulosis Paru', 11(1), pp. 1-9.

Kalsum, U. and Nur, A. (2020) 'Efektivitas Health Promotion terhadap upaya pencegahan kekambuhan dan kontrol asma', Jurnal Penelitian Kesehatan" SUARA FORIKES"(Journal of Health Research" Forikes Voice"), 12(2).

Kemenkes RI (2017) Penyakit Jantung Penyebab Kematian Tertinggi. Available at: http://www.depkes.go.id/article/view/17073100005/penyakit-jantung-penyebab-kematian-tertin ggi-kemenkes-ingatkan-cerdik-.html (Accessed: 15 August 2019).

Kemenkes RI. (2018). Riskesdas 2018. Badan Penelitian dan Pengembangan Kesehatan RI. Jakarta

Lestari, C. (2014) ‘Pengaruh Pelatihan Bantuan Hidup Dasar Pada Remaja Terhadap Tingkat Pengetahuan Menolong Korban Henti Jantung'. FKIK.

Meaney, P. A. et al. (2013) 'Cardiopulmonary Resuscitation Quality: Improving Cardiac Resuscitation Outcomes Both Inside and Outside the Hospital', Circulation, 128(4), pp. 417-435. doi: 10.1161/CIR.0b013e31829d8654.

Mommychi (2014) Pertolongan Pertama Anak Tersedak I Artikel I Mommychi. Available at: https://mommychi.co.id/id/ViewArticle/120/pertolongan-pertama-anaktersedak (Accessed: 14 August 2019).

Notoatmodjo, S. (2012) 'Promosi Kesehatan dan Perilaku Kesehatan, Jakarta: Rineka Cipta', Prince, SA (2005). Patofisiologi: Konsep klinis proses-proses penyakit.

Nur, A. and Kep, S. (2017) Buku Saku Keperawatan dan Kebidanan. Celebes Media Perkasa.

Sanghavi, P. et al. (2015) 'Outcomes of basic versus advanced life support for out-of-hospital medical emergencies', Annals of internal medicine. Am Coll Physicians, 163(9), pp. 681-690. 
Thygerson, A. (2009) 'First Aid: Pertolongan Pertama Edisi Kelima', Jakarta: Penerbit Erlangga.

Vandeput, J. J., Tanner, J. C. and Boswick, J. (1997) 'Implementation of parameters in the expansion ratio of mesh skin grafts.', Plastic and reconstructive surgery, 100(3), pp. 653-656.

World Health Organisation (2015) 'Risk Reduction and Emergency Preparedness', WHO Document Production Services, Geneva, Switzerland, p. 20. Available at: http://www.who.int/hac/techguidance/preparedness/emergency_preparedness_eng.pdf. 